Please note that tables/figures that are referred to in this article are not available on the post-print version. For the full article with tables/figures please click on the link below.

http://onlinelibrary.wiley.com/doi/10.1002/tea.20419/full

\title{
Globalizing Students Acting for the Common Good
}

\author{
Journal of Research in Science Teaching \\ Special Issue: Globalization - Science Education from an International Perspective
}

\section{Larry Bencze and Lyn Carter}

\begin{abstract}
It is apparent that many of us live in a hyper-economized world, in which personal identities and routine practices are significantly oriented towards production and consumption of for-profit goods and services. Extreme consumerism resulting from this orientation often is associated with many personal, social and environmental problems. Implicated as an agent, among many, in this problematic hyper-economized process is science education. Briefly, our literature reviews suggest that, under influences from apparently hegemonic forces of neoconservatism and neoliberalism, school science often functions to generate knowledge producers, including engineers, scientists and other theoretical workers - who, in turn, may develop and manage mechanisms of production of goods and services on behalf of global economic elite. At the same time, it also is apparent that school science generates a large class of citizens who are prepared, essentially, to serve as consumers - both in terms of faithfully following labor instructions from the aforementioned knowledge producers (who may be accountable mainly to their financiers) and also enthusiastically engaging in repeating cycles of consumption of goods and services. Such a use of education seems undemocratic, at the very least, and highly problematic, assuming an association between school science and many personal, social and environmental problems. To perhaps bring about a more just and sustainable world, we offer a theoretical framework, along with a more pragmatic version of it, for organizing science and technology education in many contexts. Although based on principles like holism, altruism, realism, egalitarianism, and dualism that we suggest may help school science generate a citizenry willing and able to proactively contribute to the common good, we also urge readers to use it as a basis for further research and development.
\end{abstract}

Keywords: globalization, science, education, neoconservative, neoliberal, activism 


\section{INTRODUCTION}

When many of us think of changes in science education, a term from physics often comes to mind: inertia. It's as if an invisible hand is inhibiting change and encouraging perpetuation and, perhaps augmentation of, the status quo. Science educators, teachers and others have a long tradition of brave efforts to transform school science in ways that might improve the wellbeing of individuals, societies and environments (WISE). Many of these efforts, including those emanating from the USA (e.g., NRC, 1996) and England (DfES, 2004), have been couched in terms of developing students' 'scientific literacy.' Although this construct is subject to varying interpretations (e.g., De Boer, 2000; Kolsto 2001), it seems useful to think of it as including these four broad domains:

- Learning Science and Technology: acquiring and developing conceptual and theoretical knowledge in science and technology, and gaining familiarity with a range of technologies.

- Learning About Science and Technology: developing an understanding of the nature and methods of science and technology, an awareness of the complex interactions among science, technology, society and environment, and a sensitivity to the personal, social and ethical implications of particular technologies.

- Doing Science and Technology: engaging in and developing expertise in science inquiry and problem solving; developing confidence and competence in tackling a wide range of 'real world' technological tasks.

- Engaging in Sociopolitical Action: acquiring the capacity and commitment to take appropriate, responsible and effective action on matters of social, economic, environmental and moral-ethical concern (Hodson, 2003, p. 658).

Despite official sanctioning (e.g., NRC, 1996) and considerable efforts to promote such a broad conception of science literacy, it is apparent that actual school science practices tend to be much more narrow in scope. Bell (2006), for example, describes the dominant scenario this way: "In the typical classroom, instruction has focused almost exclusively on the well-established products of science [the first domain, above] and cookbook approaches to laboratory exercises, using authoritarian teaching modes" (p. 430). This focus, in turn, appears to limit the extent and nature of attention to the other three domains. Crawford (2007), for example, laments that teachers are having difficulty "creating classroom environments that are inquiry-based, and that support their students in developing informed views of scientific inquiry and the nature of science" (p. 613).

Although there are, undoubtedly, complex factors impinging upon teaching and learning situations that might help explain the general inability to achieve the types of broad conceptions of science literacy, such as that described by Hodson (2003), the enduring focus on widely accepted achievements of fields of science and technology requires reexamination within contemporary conditions. Unlike educational policy and comparative education literatures, for example, which utilize economic and political perspectives for contemporary analyses, science education has been slow to acknowledge impacts of powerful forces like globalization. In this paper, we explore ways in which science education and, especially, economic globalization may be mutually entwined categories - where globalization has become the macro-level sets of forces shaping the conditions for and being expressed within science education, and science education circulates and indigenizes globalization. We also offer readers a theoretical framework, along with a more pragmatic version of it, for organizing science and technology 
education in ways that might counter effects of economic globalization and contribute to improvements in the wellbeing of individuals, societies and environments.

\section{Global Economization and Science Education}

\section{The Capitalist Zeitgeist}

The term globalization is a contested and highly unstable notion whose conceptual terrain and content is far from determined. Kaylan (2010) reminds us that it "signifies nothing other than itself ... [and as an] impossibly wide term, include[s] everything ... [and] is as flexible as it is pervasive" (p. 546). In this vein, Sovacool (2010) advises that the term can become so reified that it may occlude its complexity and, especially, its uncertain effects in any given context. This includes the possibility that nation states and local jurisdictions can resist globalization (Pan, 2010). Despite globalization's nebulous state, it may be useful to explore frequent claims about it. It is, for instance, considered a complex global spreading and linking of entities, categories of which include: cultural globalization or the spread of language, products, customs, biological globalization of organisms like people, flora, fauna and microorganisms, political globalization involving interactions among governments and non-governmental organizations, and economic globalization or trade liberalization and international monetary sharing (Stiglitz, 2003). Although these and other forms of globalization are highly interactive and simultaneous, those like Harvey (2010) regard capitalist economic globalization as the most foundational category (also see Bakan, 2003; Barber, 2007; McMurtry, 1999). Similarly, Gabbard (2000) argues that global economization "subordinates all ... forms of social interaction to economic logic and transforms nonmaterial needs ... into commodities" (p. xvii). Under this ethic, people increasingly base their identities and senses of fulfillment on economic exchanges.

Although capitalism has existed for centuries, its present neoliberal form is seen as dominating the zeitgeist of many societies. Neoliberalism is an extreme form of economic liberalism, an ideology dating from at least the eighteenth century positing that general societal wellbeing will arise when individuals are free from state interference to pursue their own economic self-interests. Unlike traditional economic liberalism, neoliberalism promotes strategic profit-oriented intervention by governments and by relatively new 'governing' entities; that is, supranational $^{l}$ organizations like the International Monetary Fund (IMF), the World Bank (WB) and the World Trade Organization (WTO). It is common, for example, for governments and supranational organizations to enact such neoliberal policies as: tax reductions (particularly for the corporate sector), privatization of public services (e.g., transportation and energy generation), and reduced social spending on other services, including for health care and education (e.g., Harvey, 2010). There also is greater emphasis on individual responsibility than on the public good, and reduced regulations on business activities such as international trade and environmental and labor standards (e.g., McMurtry, 1999).

There is much evidence to suggest that the globalizing neoliberal project is very powerful. Although overt military might has been used to globalize neoliberal perspectives and practices (often under the name of 'democracy') to other countries, like Pinochet's Chile in the 1970s, global economization's stretch often is more subtle. Using Foucault's (1991) notion of neoliberal governmentality, people may believe they are self-governed but, due, for example, to repeated

\footnotetext{
1 'Supranational' organizations do not have allegiance to any one country; but, rather, to global economic entities like financiers and corporations (McMurtry, 1999).
} 
exposure to messages from business-controlled news, sports and entertainment media promoting such virtues as individual responsibility, competition, excellence, efficiency, standardization, privatization and commodification, their 'choices' may lack real agency and be fully congruent with aims of neoliberalism. Such generalized, but subtle, influence on thoughts and actions of large numbers of people may be considered hegemonic. Indeed, McMurtry (1999) argues that we are in the 'cancer stage' of capitalism, by which he means that, like a malignancy, some members of a community (perhaps international financiers) have 'mutated' (although still resembling others) to the point of focusing strictly on their own self-interests while, in the process, destroying their neighbors.

It seems clear that neoliberalism does not benefit everyone. Instead, it appears to be a project of and for global economic elites ${ }^{2}$. Those in power often act - subconsciously or not — to ensure their continued status, preserving traditional social interactions and stratification. This is said to be the neo-conservative agenda ${ }^{3}$; that is, an orientation towards conserving (and augmenting) social stratification and, often, ways of being. Among implications of neoconservatism, it is suggested that wealth and wellbeing are funneled towards traditional elites, typically at the expense of the vast majority of other people and to the detriment of living and non-living environments (e.g., Apple, 2001; Carter, 2005, 2008; Gabbard, 2000). Indeed, Peter McLaren (in Calabrese Barton, 2001), has gone so far as to suggest that this project "functions systematically as a form of global pillage" (p. 848, emphasis added).

\section{Capitalist Science Education}

Given the widespread adoption of neoliberal policies, it follows that schooling throughout the world may be affected. Indeed, McLaren (2000), for example, suggested that "... the major purpose of education is to make the world safe for global capitalism" (p. 196). Similarly, Weinstein (2000) concluded that "all other educational ideologies are marginal to [capitalist perspectives]" (p. 100). Such impact on education is readily apparent in various government policy and curriculum documents, which often contain statements urging school systems to prepare students to 'compete in the global economy.' For example, the National Science Education Standards (NSES) document (NRC, 1996) describes one of the purposes of science education as "increas[ing] economic productivity through the use of knowledge, understanding, and skills of the scientifically literate person in their careers" (p. 13). Economic productivity can be increased in various ways, including, as Wood (1998) argues, by educating citizens in ways conducive to capitalists' goals and practices. Assuming that globalizing capitalism functions, to a great extent, in collaboration with fields of professional science and technology/engineering (e.g., Ziman, 2000), it follows that school science - as a requirement for higher education in those fields - may be significantly influenced by neoconservative and neoliberal perspectives. Each of these agendas is discussed separately below, remembering that they often function in harmony.

\footnotetext{
${ }^{2}$ Although people can hold power and influence over large numbers of others in a society, we are mainly referring to very wealthy people - certainly those in the top $1 \%$ of wealth strata, but also many in the top $10 \%$ of the world's economic elite (e.g., McQuaig \& Brooks, 2010). ${ }^{3}$ Although it is difficult to disentangle neoconservatism and neoliberalism, both conceptually and in practice, because they relate to economic for-profit exchanges, it is helpful to think of the neoconservative agenda as being primarily concerned with social issues, particularly social stratification, and neoliberalism mainly with economic matters.
} 
Neoconservatism and science education. Although neoconservatism is, like neoliberalism, a complex and variable term, a common general claim is that it "works to preserve traditional forms of privilege and marginalize authentic democratic and social justice agendas" (Carter, 2005 p. 571). Ways in which such effects may occur through school science are, likely, equally complex and variable. There is considerable evidence, however, that one of its effects is related to neoconservative promotion of 'knowledge economies.' In the last several decades, particularly after the second world war, there has been a steady shift from economic systems based on production of physical products to sustain human needs, like housing or the manufacturing of goods (particularly in the 'developed' world), to a focus on repeating cycles of consumption of abstractions, such as 'status,' 'fun,' 'beauty,' etc. — often promoted through advertising and branding aimed at engendering desires by people who have few needs (Barber, 2007; Usher, 2010). In such knowledge economies, relatively small numbers of professionals (e.g., scientists, engineers, accountants, lawyers, management consultants, investment bankers, authors, editors, art directors, video and film producers) are required who can, through their symbolic analytic services (e.g., abilities to analyze and manipulate symbols, including words, concepts, numbers and graphics), create/innovate objects of desire and other forms of knowledge. These professionals often direct the labor of a much larger class of workers who provide routine production and in-person services, such factory laborers and store clerks (Lankshear, 2000; Reich, 2007).

Throughout the world, there are many wonderful cases of researchers' and educators' efforts to address issues of social justice. Furman and Calabrese Barton (2007), for instance, demonstrate how marginalized 'inner city' elementary school students can be empowered through development of video documentaries. Chinn (2007), meanwhile, indicates that science teachers can, through appropriate professional development, gain sensitivities towards cultural perspectives of indigenous people. Nevertheless, common emphases in school science suggests that it can serve, essentially, as a de facto 'selection camp' for potential knowledge producers working for financiers and corporations. Its focus, as argued above, on abstractions in the form of decontextualized/reified conceptual science knowledge claims (e.g., laws \& theories), often delivered to them with few opportunities for application in personally-meaningful situations, indicates a preference for students who may have the capacity to provide symbolic analytic services. Associated with this focus is a school science tendency to expect students to discover such abstractions through inquiry-based learning approaches (Crawford, 2007). Their abilities to do so, however, may not be equally distributed among students. They appear to depend, to a great extent, on students' existing conceptual frameworks, knowledge and abilities to work in the abstract, etcetera; that is, forms of cultural capital ${ }^{4}$ (Bourdieu, 1986) that are associated with symbolic analytic services (Bencze \& Alsop, 2009). Relatively few students, mostly those from advantaged homes, seem able to easily discover particular, pre-specified, abstractions from inquiries. As Wellington (1998) noted, “... practical work is still not a good tool for teaching theory ... Theories involve abstract ideas which cannot be physically illustrated" (p. 7, italics in original). Carter (2010), too, has argued that, under contemporary cultural conditions, studentcentered inquiry methods have been reinvigorated as neoconservatism and neoliberalism's pedagogies of choice. Cultural capital in science classes is further enacted in students' control of prestige discourse practices. Lemke (2001) notes that "curricula and teaching methods are ...

\footnotetext{
${ }^{4}$ Cultural capital refers to the 'richness' of a person's knowledge, meta-knowledge and abilities that allow the person to survive in a culture. Experiences with abstract talk, encouragement to read and access to new technologies seems important in Western industrialized cultures.
} 
most closely adapted to the needs of middle- and upper-middle-class, culturally North EuropeanAmerican, fluent speakers of prestige dialects of English" (p. 306).

Taken together, it seems that advantaged children continue to function well with school science systems. Education (read science education) that sorts students according to their existing cultural capital, rather than attempting to promote real equity, seems undemocratic. Such education may contribute to well-documented increasing worldwide differences between rich and poor. According to McQuaig and Brooks (2010), for example, there has been a steady increase in the number of billionaires $(\geq 1,000)$ over the last few decades. This is at the expense of the wellbeing of the vast majority of other people on the planet - in terms, for example, of their income, job security and social and environmental security protections. Although the complexities of wealth accumulation and power politics preclude a precise connection between characteristics of school science and such stark socio-economic stratification, science education's overall exclusionary tendencies suggests an association. This, in turn, points to the need for dramatic school science reform in ways that would help lead to more socio-cultural equity. Hodson's (2003) fourth domain seems better suited to this task, and we return to it below.

Neoliberalism and science education. It is apparent that contemporary school science practices also align well with neoliberalism; that is, with strategic policies and practices that maximize profits, mainly for the world's economic elite. This seems to occur because education tends now to be conceived, although perhaps it always was, as both a 'good' and a 'service' transacted within economic markets broadly shaped by supranational organizational and national governments neoliberal policies. What is enacted at broad policy levels may trickle down to classroom practice. Briscoe (2000), for example, argues that "one of the fundamental ends of the new efficient, pervasive, and invasive school disciplinary regimes is to form students whose knowledge, abilities, skills, insights, dreams, and moral vision are shaped towards economic ends" (p. 68).

A critical analysis of school science systems from the political and economic perspective we have adopted here argues that science education contributes to development of both knowledge builders (e.g., professional scientists) and large numbers of citizens who are highly conditioned for consumption. Giroux and Giroux (2006) are among those who have identified two types of consumer orientations generated by schooling. The first orientation may be seen in the large group of workers who dutifully follow knowledge instructions from knowledge producers. The second orientation may be seen in ways people enthusiastically consume/purchase products and services and their associated abstractions - like brands and status, both real and virtual. Ways in which school science systems may contribute to such a consumerist society are, undoubtedly, complex. Work in the broader globalization field, though, when coupled with relevant science education literature, suggests that neoliberalism is promoted in school science around two broad and interrelated themes; that is, perspectives and abilities.

Perspectives. The emphasis, as noted above, on Hodson's (2003) first domain of school science in most classrooms may well orient students' perspectives towards consumerism and passive ones at that! A steady diet of conclusions can stifle students' desires to ask questions, critique claims, criticize those who control knowledge and develop their own conclusions (Wood, 1998). Simultaneously, the neoliberal necessity of competition noted above may be promoted by the scarcity of rewards among students. The delivery mode of the 'products' and their corresponding assessment and evaluation through standardized instruments of all sorts demonstrate to students that there are clear 'winners' and 'losers.' For Shapiro (2000), "[p]ersonal struggle, competitiveness, atomization, and scarcity of success or 
well-being are the constitutive elements of both the social[-economic] and the educational world" (p. 104). This individualization of learning, another hallmark of neoliberalism (Carter, 2010), may limit students' perspectives about their capacities to contribute to the common good. This can manifest as a disengagement in issues outside of students' own selfinterests, an example of which would be students' 'delinking' in the relationships between hyper-consumption and environmental degradation (Mignolo, 2008). Individualization and delinking seem ideologically aligned with corporations' legal right to maximize profits by, in part, externalizing costs; that is, encouraging others to pay for such expenses as health and environmental side-effects of their products and services (Bakan, 2004).

Looking further, students' consumer perspectives may be facilitated, we suggest, through both mis-representation and representation of the nature of fields of science and technology (NoST). Although NoST is a highly contested domain (Hodson, 2008), many authors believe, nevertheless, that school science often misrepresents these fields by casting them in an overly positive light. In a review of historical representations of science in school science for instance, Allchin (2003) concluded that the following "mythconceptions" about science were promoted: Monumentality: scientists appear as 'larger-than-life' heroic figures, often working alone and, moreover, their work is seen as very difficult, but very important; Idealization: false starts, complexities and biases are absent; Affective drama: the excitement and emotional elation of 'discovery' are exaggerated; and, Explanatory and justificatory narrative: conclusions are seen as final/unchanging and correct” (pp. 341-347). A broad way of thinking of such portrayals is in terms of Loving's (1991) Scientific Theory Profile (STP) ${ }^{5}$. Overall, Hodson (2008) argues, school science systems usually lead students to, in effect, hold Rationalist-Realist views about professional science - which suggest that knowledge development is highly logical and systematic, and that knowledge claims can fully represent phenomena. Those adhering to Naturalist-Antirealist positions, meanwhile, would suggest that Rationalist-Realist portrayals mis-represent fields of science, noting, for instance, that scientists like Charles Darwin frequently ignored disconfirming data in order to protect their favored theories (Allchin, 2003).

Apparent misrepresentations of science can occur through omission as much as commission. Again, from a Naturalist-Antirealist perspective on the STP, the tendency of school science systems to omit references to potentially negative influences of corporations and financiers on practices and products of fields of science and technology can be misleading (Carter, 2005). Although many suggest science and technology have contributed to human wellbeing, there is a significant body of contemporary sociological research

${ }^{5}$ This is a 2-dimensional grid, with lines of equal length intersecting each other at right angles in the middle of each line. The horizontal axis spans a continuum ranging from Rationalist through Naturalist positions regarding the nature of theory negotiation in the sciences. Rationalists tend to believe in highly systematic methods of science, including rational judgements about theory. Naturalists, by contrast, assume that the conduct of science is highly situational and idiosyncratic, depending on various factors, including psychological, social, cultural and political influences. The vertical axis, meanwhile, depicts a continuum reflecting the truth-value of knowledge, with Realist through Antirealist positions. Realists believe that scientific knowledge corresponds to reality, while (extreme) Antirealists claim that each person's constructions are valid. These continua have 'ordinal' scales. On the Rationalist-Naturalist continuum, for example, placing a mark close to the 'Rationalist' end indicates a 'strong' Naturalist view about science. Placing a mark about mid-way between the two poles, by contrast, indicates that science has moderately Rationalist and Naturalist features. 
indicating that business-science partnerships are not always beneficial to individuals, communities and environments (Bencze, 2008; Ziman, 2000)). These include hazards associated with products of industries that may be under-regulated in some areas of the world, such as pharmaceuticals (e.g., Angell, 2004), biotechnologies (e.g., Krimsky, 2003) and manufactured foods (e.g., Schlosser, 2001).

Again utilizing our political and economic lenses of critique, it is plausible to argue that if school science systems misrepresent professional science and technology, they are, essentially, providing business and industry with infomercials for their products and services. Representation of the 'product' to be sold, that is, professional science and technology, becomes reified to the point of being a simulacrum (Baudrillard, 1998) ${ }^{6}$. Gough (1998) describes many ways in which school science laboratory-based lessons and activities can be like a simulacrum, suggesting that there is one logical science method, scientists work independently in laboratory settings (often resembling those of the $19^{\text {th }}$ century), and conclusions are certain. Consequently, school science may be so detached from reality of professional science and technology that students' views of them can be, unwittingly or otherwise, manipulated to suite various purposes. In the context of neoliberal knowledge economies, this often is achieved by encouraging citizens to develop (and re-develop) personal identities, senses of wellbeing and solidarities with others associated with consumption of semiotic actants (e.g., signs) (e.g., Barber, 2007; Sovacool, 2010; Usher, 2010), such as the positive perspectives described by Allchin (2003), noted above, that might be communicated to students.

Perhaps one of the few ways in which fields of professional science and technology may be well-represented by school science systems is in terms of their economized characteristics. The aforementioned promotion of individually-competitive struggles for science literacy is a case in point. That the objects of these struggles may be highly reified, like correct labeling of an idealized drawing of a cell, students would, in effect, be competing for a commodity; that is, an entity that has been 'packaged' - often involving significant decontextualization — into a form amenable to exchange. Here, students would be exchanging memorization of science knowledge or 'commodities' for marks/grades. In doing so, moreover, they also may come to believe that such commodities can be owned by individuals. Such perspectives can be reinforced when educators encourage students to celebrate achievements of individual scientists like Nobel Prize winners (Hodson, 2008). This stands in stark contrast to notions of social epistemology, which posit that knowledge is historically and socially constructed and, in a sense, belongs to everyone past, present, and future (e.g., Alperovitz \& Daly, 2008; Fuller, 2002). Nevertheless, such commodified views of science knowledge align well with neoliberal principles. "Neoliberalism 'marketizes' everything, even notions of subjectivity, desire, success, democracy, and citizenship, in economic terms ..." (Carter, 2005, p. 571).

Abilities. In addition to their perspectives, student abilities also may be shaped by the 'invisible-hand' of neoliberal ideology. That school science focuses on learning goals, pedagogies and outcomes within neoliberalism's narrow preference for possessive individualism, students' development of science literacy is, potentially, compromised. Even if students wish to break from their assigned role of consumption and, instead, critique the

\footnotetext{
${ }^{6}$ A simulacrum, according to Baudrillard (1998), refers to a human construction that is so detached from reality that it becomes an entity in its own right, a state he called the 'hyperreal.' Being detached from reality, such constructions can then be used for certain purposes without concerns about questions of its connections to reality.
} 
status quo, their abilities and capacities to do so can be significantly attenuated. Our review of literature suggests that this is a consequence of two, not necessarily unrelated, themes; that is, the lack of breadth and depth of attention to literacy goals.

Despite intentions for and claims about inclusion of a breadth of learning goals in science curricula world-wide, it is apparent, as argued above, that school science systems tend to restrict breadth of instruction to a focus on products of professional science and technology. Consequently, students' access to literacy outcomes within the latter three of Hodson's (2003) four domains may be limited. Indeed, much educational research suggests that school science often struggles to help students to develop literacy in terms of NoST (e.g., Abd-ElKhalick \& Lederman, 2000), science inquiry skills (e.g., Crawford, 2007), and sociopolitical activism to address SSIs (Hodson, 2003). Without such expertise, students are restricted in the extent to which they might, for example, critique and suggest revisions about sciencesupported business practices and their goods, services and associated symbolic messages.

Limitations on students due to the narrowness of official school science learning goals may be compounded because of their standardization in curricula within and among jurisdictions, along with relatively tight surveillance practices (e.g., testing) and reporting. This confines knowledge, skills and so on to those considered important by the prevailing and often neoconservative economic elite who authorize acceptable claims. This, in turn, pressures cultural, ethic, religious and other societal sub-groups to conform to the designated standards, not only losing their uniqueness in the process but also devaluing the diversification touted under globalization. This creates an intractable tension that comes to the fore in many of the world's conflicts. Aikenhead and Jegede (1999) have commented that "around the world, ... science students are expected to construct scientific concepts meaningfully even when those concepts conflict with indigenous norms, values, beliefs, expectations, and conventional actions of students' life-worlds" (p. 270). This conformity to a narrow set of standards is magnified, moreover, because of the individualized nature of assessment and evaluation, where students are excluded from tapping into perspectives and practices of others. Putnam (2000) notes that the decline in social capital, which would allow people to draw from diverse strengths of others, is a characteristic of highly competitive (read neoliberal) economies. While conformity to standards may be a threat to certain subgroups' self-determination and individuals' possibilities, it is beneficial to business interests, allowing for benchmarking of for-profit exchanges (Apple, 2001).

Given the tendency for school science systems to focus instruction on products of science and technology, research tells us that the depth to which students develop these and other learning outcomes is frequently compromised. The sheer number of products in curricula can compel teachers to cover them so rapidly and with few opportunities for application in personally meaningful contexts that many students are left confused or only capable of rote learning (Jenkins, 2000). In other words, being a student of school science often is like trying to take a sip from a fire hose! In a compensatory mode, teachers often overly guide student learning, falling back on time-honored direct instruction pedagogies. Rarely, if ever, do students have opportunities to do science in school science. In other words, texts or teachers control decisions about areas of exploration, questions or problems to solve, methods of data collection, analysis as well as critique and decisions about conclusions from investigations. Even with inquiry-based learning activities, through which students might believe they are freely constructing knowledge, teachers often guide topic choice, methods, conclusions and dissemination (Bencze \& Alsop, 2009). Wenger (1998) has argued, using knowledge duality 
theory, that meaningful learning may be enhanced when there are close, reciprocal, relationships between phenomena like, for example, cells and their representations (e.g., drawings). Where students' activities are excessively controlled by others, their involvement in such reciprocal relationships, such as using their representations in empirical tests under their control, is likely limited and, consequently, the depth of their learning may be restricted. Without depth of learning, students' abilities to critique, create and disseminate knowledge is hindered - a potential void to be filled by the types of consumptive mechanism already outlined.

When taking a political and economic perspective on current school science, there is emerging evidence that neoconservative and neoliberal ideologies are embedded within policies and practices. While tracing these influences is in its infancy and highly complex, the work is crucial to understand science education of the $21^{\text {st }}$ century in the globalized world. At stake is the development of a de facto 'scientific literacy' that promotes rather than reduces consumption, orients towards egoism, and suppresses rather than promotes the common good - all to the detriment of the global environment and future sustainability (Kahn, 2010, pp. 51-52). Apart from more localized and subtle negative effects of capitalist science and technology and science education, such as health hazards associated with manufactured foods (as outlined above), for example, the need for a veritable paradigm shift may be more clear in light of such dramatic and globally-influencing potential problems as climate change. According to the Intergovernmental Panel dealing with this issue, for example, Earth may be on course for catastrophic loss of life and social re-distribution, assuming the currently-predicted average global temperature increases by about $6^{\circ} \mathrm{C}$ within the next 100 years (Lynas, 2008). Dobbin (2000), for example, finds this unjust: "[O]ur collective will is declared meaningless compared to the values of the marketplace, and communitarian values are rejected in favour of the survival of the fittest" (pp. 1-2). To the extent that neoliberal capitalism is having effects on school science students such as those discussed above, it needs to be revisited and replaced with a more democratic form of science education.

\section{Towards Globalization of a Just Science Education}

There are, undoubtedly, several ways in which school science could be transformed to address many of the potential problems apparently associated with neo-conservative/liberal capitalism noted above. Although it might involve many changes, a promising and relevant focus of reform pertains to education regarding socioscientific issues ${ }^{7}$ (SSIs). Although the precise meaning of this term is subject to debate (e.g., Pedretti \& Nazir, 2011; Zeidler et al., 2005), we suggest it broadly entails disagreements about merits of particular relationships among fields of science and technology and societies and environments. A typical SSI relates to the relative merits of nuclear electrical generation, given difficulties associated with disposal of its potentially harmful radioactive by-products. Due to the breadth and depth of such issues, many jurisdictions have increased priority in curricula towards addressing them (Zeidler et al., 2005).

\footnotetext{
7 This term is one of several in use to describe issues or potential problems stemming from interactions among fields of science and technology and societies (or, more likely, interest groups in them). 'Socioscientific issues (SSI)' are, more or less, synonymous with 'STS' or 'STSE' issues, the former referring to relationships among fields of science (S) and technology $(T)$ and societies (S), while the latter also considers environments (E). Different authors tend to use different terms for approximately the same meaning.
} 
In support of such mandates, many researchers and developers have explored approaches for helping teachers and student-teachers to enact the new learning expectations. Roth (2009), for example, reports on student participation in data collection and subsequent lobbying actions related to local citizens' access to municipal water. Associated with such approaches, educators report diverse student learning outcomes, including: awareness of and personal positions relevant to particular issues (e.g., Furberg \& Ludvigsen, 2008); development of socioscientific reasoning skills (e.g., Sadler et al., 2007); learning of products of science (e.g., laws \& theories) (e.g., Castano, 2008); and, learning about the nature of science (e.g., Khishfe \& Lederman, 2006).

Although considerable progress has been made in development and research relating to students' education regarding socioscientific issues, actual practices in schools often are much more modest. There are, undoubtedly, different ways this may be analyzed and evaluated. A convenient schema, because of its relative simplicity, has been developed by Hodson (2003) who suggested that education in this domain can occur at four levels of sophistication; namely:

I. Appreciating the societal impact of scientific and technological change, and recognizing that science and technology are, to some extent, culturally determined.

II. Recognizing that decisions about scientific and technological development are taken in pursuit of particular interests, and that benefits accruing to some may be at the expense of others. Recognizing that scientific and technological development are inextricably linked with the distribution of wealth and power.

III. Developing one's own views and establishing one's own underlying value positions.

IV. Preparing for and taking action [to address SSIs] (p. 655).

Where it occurs, education relating to SSIs tends to be limited to the above first three levels. Although students might be asked to negotiate some contentious issues and attempt to defend their positions on them (e.g., Furberg \& Ludvigsen, 2008; Sadler \& Zeidler, 2004), they are rarely asked to prepare for or, even less likely, to take action to address SSIs (e.g., Hodson, 2003; Santos, 2009). Forms of action students might take include: educating others (e.g., via posters and pamphlets), lobbying power-brokers (e.g., via petitions and letters) and/or making personal improvements (e.g., using a travel mug) (e.g., Bencze \& Alsop, 2009). Reasons why students generally do not take such actions are likely many and varied. It may, for example, be as Hodson (2003) suggested: "It is almost always much easier to proclaim that one cares about an issue than to do something about it!" (p. 657; emphases added). In light of arguments above, however, it also seems plausible that a de-emphasis on activism occurs because, in part, it inherently involves a giving of at least a part of oneself to others - which would be antithetical to the tendency of school science systems to promote possessive individualism.

There are many reasons to encourage and enable students to take actions to address socioscientific issues. Many authors suggest the potential (if not already realized) seriousness of problems that may arise from them is warrant enough (e.g., Bencze, 2008; Calabrese Barton 2001; Gabbard, 2000; Hodson, 2003; McLaren, 2000; McMurtry, 1999; Roth \& Désautels, 2002; Santos, 2009). Without an activist citizenry, the wellbeing of individuals, societies and environments may be in peril. Beyond such dire scenarios, however, it can be argued that student activism may help them to develop deeper, more meaningful conceptions of issues - because, using knowledge duality theory, deep, attached, learning may arise when there are relatively close reciprocal associations between phenomena of the world (e.g., toxic metals in cell phones) and a person's representations (e.g., notes about the toxins, and suggested actions to address them) of them (Wenger, 1998). This may, indeed, be crucial in the sense that neoliberalism often creates (as described above) such a 'hyperreal' world that people can be manipulated by 
manufactured representations (e.g., those in advertising) that have minimal attachments to phenomena (Baudrillard, 1998). Usher (2010) suggests "hyper-reality is ... the major condition of contemporary life" (p. 39, emphasis added). In terms of the nature of meanings, we also may be wise to act for the common good - since, in light of social epistemological claims that all knowledge and events are a collective responsibility (Fuller, 2002), acting well for others may, albeit not for completely altruistic reasons, engender personal wellness (Eiglad \& Bookchin, 2007). At the same time, in congruence with the 'Engaged' Science and Technology Studies program (Sismondo, 2008), actions for the common good are "less concerned with understanding science and technology [perhaps including their relationships with societies and environments] in and of themselves, and more with making science and technology accountable to public interests" (p. 18; emphasis added) — what Fuller (1993) called 'Low Church' STS. Finally, there is evidence to suggest that citizen activism can be successful - such as when AIDS activists uncovered and addressed unethical practices regarding clinical drug trials (Epstein, 1996).

\section{A Theoretical Framework for Activist Science and Technology Education}

[Insert Figure 1 about here]

Given the relative paucity of references to activism in research and pedagogy relating to socioscientific issues, there may be a need for theoretical frameworks that prioritize sociopolitical activism in science education. Since 2006, we have used the 'STEPWISE', framework in Figure 1 for this purpose. The original version of the model was developed by the first author here (LB), but it has evolved in its details (e.g., terminology) and layout (e.g., shape) to accommodate implementation experiences and theoretical considerations. Nevertheless, general principles on which it was conceived have remained unchanged. We believe that this framework may serve as a useful counter-point to many science education approaches that seem to be associated, as argued above, with neo-conservative/liberal ideological perspectives along with related adverse personal, social and environmental side-effects of business activities. It does, in brief, address all four domains of science literacy promoted by Hodson (2003) — on which our critique of capitalist science education is, in part, based. Brief notes about some of the more prominent principles inherent to STEPWISE, along with justification for each, are provided below (supplementing points provided in Figure 1):

- Holism: A major consideration in developing this framework was to address the tendency of school science systems to compartmentalize instruction and assessment - a tack arguably associated with businesses' preference for individualization and decontextualization. It is not uncommon, for instance, for 'STSE Education' (or SSI education) to be addressed - if at all - after 'Products Education' is fully addressed. The STEPWISE framework was designed to acknowledge that learning in any one domain (e.g., Skills Education) is and should be reciprocally related to learning in every other domain. Students' learning of 'Products,' for example, is likely to depend on and influence their STSE conceptions (Hodson, 2003). This also implies that teaching and learning can begin (and end) with any domain - which is congruent with the view that thinking and doing are situated (not decontextualized) (e.g.,

${ }^{8}$ For a fuller description of STEPWISE, refer to: http://www.stepwiser.ca . 
Brown et al., 1989; Gruenewald \& Smith, 2008) and, moreover, are collective activities entailing contributions unique to each participant (e.g., Roth \& Barton, 2004).

- 'Altruism': For reasons such as those given above, socio-political activism ('STSE Actions') is placed in the middle of the framework. Among the many implications of this placement, it is perhaps most important to note that students would be 'spending' — in, arguably, altruistic ways (Batson, Ahmad \& Tsang, 2002) - at least a portion of their cultural and social capital (Bourdieu, 1986) on the common good, in contrast with science education that orients students towards possessive individualism (refer above). Students might, in other words, devote at least some of their education in the peripheral domains (e.g., 'Products Education') of the framework as bases for sociopolitical activism. Indeed, because of the reciprocal nature of each domain pair, students may be motivated to learn in any of the peripheral domains because they view such learning as potentially useful for the common good.

- 'Realism': On the one hand, given the dynamic and contextualized nature of any one actant in a network (e.g., Latour, 2005), it is, arguably, inappropriate to make specific claims about phenomena, ideas, etc. Nevertheless, in light of school science systems' frequent tendency to portray fields of science and technology in overly positive ways (refer above), we feel that it is necessary to represent a range of perspectives from science and technology studies including, for example, that there often are complex interactions between fields of science and technology (e.g., Roth, 2001); and, that interest groups (e.g., neoliberals) can affect practices (e.g., Skills, Products) in fields of science and technology (e.g., Krimsky, 2003). Such a tack appears to be aligned with the 'Engaged' Science and Technology Studies program, which recognizes connections among fields of science and technology and societies (and environments) and, moreover, frequently prioritizes efforts to make improvements to them (Sismondo, 2008; refer above). Since students would be continually reflecting on the nature of science and technology (including with regards to their relationships with each other and with societies and environments) and ways in which they may be revised, such an orientation may be thought of as a kind of 'critical and emancipatory metacognition.'

- Egalitarianism: Despite recognition of the complex and dynamic nature of actor networks, which might imply a balance of forces throughout them, we also feel that there are, commonly, 'disturbances,' inequities, etc. in such systems. Indeed, as argued above, it is apparent that some school science practices may disadvantage students who lack social and/or cultural capital (e.g., Bencze \& Alsop, 2009). Consequently, a principle inherent to the STEPWISE framework is to disturb school science networks in ways that may engender social equity (along with other aspects of WISE). Teachers could, for instance, use various pedagogical approaches to help ensure marginalized students are at least able to learn about ideas and perspectives of the dominant class, while maintaining their cultural identities (e.g., Aikenhead \& Jegede, 1999).

- Dualism: Among 'disturbances' in educational actor networks, particularly those strongly influenced by a few powerful economic elite, is that students often are presented with abstract representations (e.g., drawings of cells) of phenomena (e.g., cells) that are so detached from the entities that they purport to represent that they may be, as discussed above, reified to the point of irrelevance to particular contexts (e.g., a person's personal life). Accordingly, for most learning situations based on STEPWISE, efforts are made to engage students in reciprocal interactions between phenomena of the world (e.g., trans-fatty acids in manufactured foods) and representations associated with them (e.g., data from their primary research indicating a correlation between gender and trans-fatty acid use) - a tack thought to 
promote deep, personal, meanings (Wenger, 1998). This contrasts, as argued above, with more superficial and short-lived meanings frequently developed in school science systems strongly influenced by neo-conservative/liberal perspectives.

Since 2006, we have been working with teachers and student-teachers (in our respective cities) to study their ongoing efforts to implement the STEPWISE framework in Figure 1 in their educational contexts (grades 5-12). Many of our findings, generally drawn from qualitative data analyzed using constant comparative methods based on constructivist grounded theory (Charmaz, 2006), have been published in refereed journal articles and book chapters, and in proceedings for refereed conferences (e.g., Bencze \& Alsop, 2009; Sperling \& Bencze, 2010). An early conclusion was that, although a teacher may have experiences (e.g., activism work) and belief systems (e.g., views about NoST) that seem congruent with successful implementation, various contextual variables may limit their success (Bencze et al., 2008). It is common, as might be predicted from the above arguments, for teachers to indicate, for example, that implementation is difficult because their teaching colleagues overly prioritize instruction in 'Products Education' and, indeed, insist that this be prioritized on tests and examinations that all students in their respective sections of a course must take. Given what has long been known about the situational nature of teaching and learning (e.g., Brown et al., 1989) and in light of the complex and dynamic nature of any one actant in a network of reciprocal interactions among animate and inanimate actants (Latour, 2005), such a finding is, perhaps, unsurprising. A corollary of this claim, however, is that it is very difficult for us to predict the nature and extent of any one teacher's efforts to organize teaching and learning in a particular context on the basis of the framework in Figure 1. Different contexts may be more or less amenable to it.

\section{A Pragmatic Framework for Activist Science and Technology Education}

[Insert Figure 2 about here]

In working with teachers and student-teachers associated with science education in grades 512, we have found that implementation of the theoretical framework in Figure 1 is extremely difficult. Indeed, to date, none of the educators with whom we have worked have been able to implement, in its 'purist' sense, this theoretical version — which, among other things, implies that education can start anywhere in the framework. Consequently, although we believe that the framework in Figure 1 is most philosophically valid (refer above) and should be broadly adopted, we have, particularly in the context of one-on-one lesson planning sessions with teachers, found that they are more comfortable with a linear version of it - the latest edition of which is given in Figure 2. Many readers of this article may find this version useful, although we would be very interested in future publications that describe teachers' successes in implementing what we believe to be the more philosophically-sound framework in Figure 1.

The schema in Figure 2 can be construed as a deficit conception of education; that is, assuming learners arrive in instructional situations deficient in knowledge, skills, etc. prioritized by controllers of education. This contrasts with constructivist learning theories that view the learner as possessing pre-instructional conceptions, skills, etc. that can influence learning and, perhaps more importantly, can and should be a significant basis for educational engagement (e.g., Swartz, 2009). Nevertheless, teachers with whom we have worked have felt that it is important to first increase students' 'literacy' — such as by attending to the peripheral domains 
in Figure 1 - before asking them to conduct sociopolitical actions to address STSE issues. As indicated in Figure 2, teachers generally felt that two broad instructional categories are helpful; that is, i) Research-informed STSE Action Apprenticeship and ii) 'Content' Teaching in STSE Contexts. Each of these broad categories combines two or more domains (refer below) from the theoretical framework in Figure 1. When teachers feel that students have had sufficient preparation with regards to these two categories, perhaps over the course of one or more curriculum units, they might require them to conduct Student-led Research-informed STSE Action Project(s). Because there is a significant body of research associated with 'Content' Teaching in STSE Contexts (e.g., Albe, 2008), our research and development focus has been on apprenticeship activities and student-led projects. Below, we provide rationale and examples pertaining to these two categories.

Research-informed STSE action apprenticeship. This broad category combines all domains from the framework in Figure 1, but especially incorporates connections among: STSE Education, Skills Education, Students' Projects and STSE Actions. The main assumption behind this category is that students are most likely to be committed to take actions on specific STSE issues if they have self-generated data associated with the issue(s) - which we believe implies the following strong connection: Students' Projects (with an STSE focus) $\rightarrow$ STSE Action(s). An emphasis on such research-informed activism is based, as argued above, on the assumption that deep, committed, learning arises when there are relatively close reciprocal associations between participation with phenomena and representation(s) of them (Wenger, 1998). During researchinformed activism projects, learners may induce 9 their representations (e.g., notes about the toxins, and suggested actions to address them) from experiences with phenomena (e.g., experiments with toxic metals in cell phones) and evaluate their representations (in deductive tests and actions) in relevant phenomenal contexts. With such engagement, students' commitments to action may be greater than if their main source of connection to STSE issues is from sources outside of themselves - such as documentaries provided by teachers.

Given teachers' concerns about students' relative lack of readiness for research-informed actions on STSE issues, the model in Figure 2 provides students with an apprenticeship (e.g., Bencze, 2000) involving two types of open-ended ${ }^{10}$ activities, methods of which are largely student-led, with some teacher scaffolding; that is, i) modeling and ii) practice regarding research-informed STSE actions. In terms of modeling, teachers can, for instance, show students that young people like them have carried out activist projects, at least partly informed by their research. Sources of such cases may come, for example, from researchers' published works. Roth (2009), for example, reports on student participation in data collection and subsequent lobbying actions related to local citizens' access to municipal water. Another excellent source of cases is internet-based video documentaries, such as one in which student 'reporters' broadcast their action suggestions regarding 'Peak Oil' (i.e., when supply outstrips demand) ${ }^{11}$. Presenting students with cases of others' research-informed STSE actions may not, however, greatly

\footnotetext{
9 Based on constructivist epistemological positions, 'pure' induction - which, theoretically, involves a direct translation from phenomena of the world to representation(s) of them - does not occur. Development of representations, accordingly, may be thought of in terms of abduction; that is, use of cognitive structures in interpreting phenomena (Lawson, 2005).

${ }^{10}$ By 'open-ended,' we are referring to activities that may have many diverse conclusions, codetermined by students. These are not intended to be 'guided discovery' activities, often referred to as 'cookbook labs,' in which conclusions are pre-set by the instructor.

${ }^{11} \mathrm{http}: / / \mathrm{www}$.youtube.com/watch?v=64dBjhiZcqM\&feature=player_embedded
} 
prepare them to carry out their own such projects. It may give them a vision of the possible but, again referring to knowledge duality theory (see above), deeper commitments may arise if they have been engaged in more self-directed (with some teacher scaffolding) small-scale researchinformed STSE action projects. In this regard, we have encouraged teachers to help students to develop expertise and confidence in conducting correlational studies, as well as experiments, as some bases for their actions. Correlational studies are commonly used in various branches of science (and technology) and, despite general lack of attention to them in schools (Bencze, 1996), they appear to be an excellent choice for investigations into potentially hazardous variables (e.g., effects of nicotine on finger yellowing) associated with STSE issues. A teacher we studied, for instance, partly scaffolded students in his eleventh-grade biology course to conduct open-ended correlational studies (e.g., comparing heart rates with fast-food consumption) to generate findings they used to produce health education pamphlets - a type of action the teacher generally required students to develop.

Student-led Research-informed STSE action project(s). After teachers believe that students have developed sufficient expertise and confidence for them, through perhaps a few apprenticeship activities like those described above (perhaps also with 'Content' Teaching in STSE Contexts, as depicted in Figure 2), they may then require students (likely in groups) to selfdirect open-ended research-informed action projects to address STSE issues of their choice. In our research, only a relatively small proportion of teachers we have studied have been able to reach the point at which students in their courses have conducted such student-led activism projects. Most teachers tell us that, essentially, school science systems' orientation towards rapid-fire and comprehensive instruction in products of science and technology leaves little time for student-led research-informed projects of any sort. One particular teacher ('Kathy'), however, appeared to not only have views conducive to promotion of research-informed activism but, as well, worked in a school that had a general culture (e.g., a Mission Statement prioritizing social justice and environmental sustainability, along with several relevant whole school campaigns) supportive of such activities. After she provided students in her tenth-grade science course with student-directed and open-ended apprenticeship activities similar to those depicted in Figure 2, Kathy gave students a detailed assignment requiring them to conduct, on a schedule, student-led and open-ended research-informed activism projects dealing with issues of their choice relating to water quality (the main subject of the unit they were studying). We, along with Kathy, concluded, after viewing students' completed projects, that student groups were successful, to varying degrees, in implementing student-directed and open-ended research-informed STSE action projects. In addition to an activist video they uploaded to YouTube ${ }^{\mathrm{TM}}$ and posters they placed on walls and bulletin boards throughout the school, one group, for example, presented to fellow students data drawn from their measurements of various contents (e.g., heavy metals) of a range of water sources and corresponding recommendations regarding use of tap, as opposed to bottled, water.

\section{CONCLUDING REMARKS}

Although local nation states and communities can and do resist effects of globalization on them and, moreover, apparently can alter the nature of globalizing forces (Sovacool, 2010), it is apparent that it is, in many ways, inexorable. Economic globalization, which appears to be the main driving force behind other globalizing entities, such as culture, politics and living things, seems hegemonic. To a great extent through processes of governmentality, it is apparent that 
actants around the world are involved in for-profit exchanges that, at the risk of a gross oversimplification, concentrate wealth and wellbeing in the hands of traditional economic elite while compromising the wellbeing of the vast majority of people and living and non-living environments. Implicated in such problematic effects often is a global orientation towards neoconservative and neoliberal ideological perspectives, which many writers suggest have taken hold of the zeitgeist of many societies worldwide. Used, arguably, as an instrument of neoconservative/liberal agendas, is science education - which, based on our literature reviews, seems to generate, among various outcomes, potential professionals (e.g., engineers, scientists, advertising professionals, business administrators, etc.) who can create abstractions for knowledge economies. Such abstractions may be used for production of for-profit goods and services, and perhaps most importantly, as notions, such as 'status,' associated with branding that can engender desires in people who, generally, have few needs to participate in repeating cycles of consumption. As a complement to this knowledge generation service, it is apparent that school science, through various mechanisms, leads students into accommodating various personal and social characteristics congruent with capitalist aims; such as: possessive individualism, overlypositive conceptions of fields of science and technology (and, by association, business and industry), and relative inabilities to, for example, create their own knowledge and critique that of others.

Given the above scenario, it seems clear that we need to ask if this is the sort of world we want to globalize. Is it the sort of world we want to pass on to our children? More particularly, given our literature-based political and economic analyses reported here, to what extent do we want to perpetuate and, indeed, entrench the kind of school science we portray? Answers to such questions, like the very nature of concepts like globalization, neoconservatism, neoliberalism, governmentality and hyperreality that we explored here, are complex, dynamic and uncertain. Nevertheless, for reasons given above, there is much evidence to suggest we need dramatic transformations in conceptions of being - including in terms of improvements in relationships among fields of science and technology and societies and environments. Given the tenacity of resistance to changes in the status quo, however, we suggest that a key element of such transformations should be development of a citizenry that is willing and able to sometimes aggressively act for the common good. Accordingly, in this paper, we have provided a theoretical framework, along with a more pragmatic version of it, as a possible way of organizing science and technology education towards such ends. Based on principles like holism, altruism, realism, egalitarianism, and dualism, we suggest that, at the very least, it may provide a basis for realizing many governments' stated intentions for promoting broad conceptions of science literacy like that described by Hodson (2003, 2008). Ultimately, we hope that it will globalize students/citizens acting for the common good. In achieving this, it may serve as an effective contribution to 'treatment' of what McMurtry (1999) claims is the 'cancer stage of capitalism.' On the other hand, like all propositions, the schema we have presented is and will be part of a complex, dynamic and uncertain actor network of global interactions. As such, anyone considering using it must, we feel, engage in revolutionary conscientization (enlightenment/awareness) and praxis (critical reflective practice) (McLaren, 2000). 


\section{REFERENCES}

Abd-El-Khalick, F., \& Lederman, N. G. (2000). Improving science teachers' conceptions of nature of science: A critical review of the literature. International Journal of Science Education, 22(7), 665-701.

Aikenhead, G.S., \& Jegede, O.J. (1999). Cross-cultural science education: A cognitive explanation of a cultural phenomenon. Journal of Research in Science Teaching, 36(3), 269287.

Albe, V. (2008). When scientific knowledge, daily life experience, epistemological and social considerations intersect: Students' argumentation in group discussions on a socio-scientific issue. Research in Science Education, 38(1), 67-90.

Allchin, D. (2003). Scientific myth-conceptions. Science Education, 87(3), 329-351.

Alperovitz, G., \& Daly, L. (2008). Unjust deserts: How the rich are taking our common inheritance. New York: New Press.

Angell, M. (2004). The truth about the drug companies: How they deceive us and what to do about it. New York: Random House.

Apple, M.W. (2001). Creating profits by creating failures: Standards, markets and inequality in education. International Journal of Inclusive Education, 5(2/3), 103-118.

Bakan, J. (2004). The corporation: The pathological pursuit of profit and power. Toronto: Viking.

Barber, B.R. (2007). Consumed: How markets corrupt children, infantilize adults, and swallow citizens whole. New York: Norton.

Batson, C.D., Ahmad, N., \& Tsang, J. (2002). Four motives for community involvement. Journal of Social Issues, 58(3), 429-445.

Baudrillard, J. (1998). The consumer society. London: Sage.

Bell, R.L. (2006). Perusing Pandora's Box: Exploring the what, when, and how of nature of science instruction. In L.B. Flick \& N.G. Lederman (Eds.), Scientific inquiry and nature of science: Implications for teaching, learning, and teacher education (pp. 427-446). Dordrecht: Springer.

Bencze, J.L. (2008). Private profit, science and science education: Critical problems and possibilities for action. Canadian Journal of Science, Mathematics \& Technology Education, 8(4), 297-312.

Bencze, J.L., \& Alsop, S. (2009). A critical and creative inquiry into school science inquiry. In W.-M. Roth \& K. Tobin (Eds.), The world of science education: North America (pp. 27-47). Rotterdam: Sense.

Bencze, L., Alsop, S., Sperling, E., Nazir, J., \& DiGiuseppe, M. (2008). Science teachers' motivation for encouraging students to promote individual, social \& environmental wellbeing. Proceedings of the annual conference of the National Association for Research in Science Teaching, Baltimore, MD, March 30 - April 2, 2008.

Bourdieu, P. (1986). The forms of capital. In J.G. Richardson (Ed.), The handbook of theory: Research for the sociology of education (pp. 241-258). New York: Greenwood Press.

Briscoe, F.M. (2000). Discipline. In D. A. Gabbard (Ed.), Knowledge and power in the global economy: Politics and the rhetoric of school reform (pp. 63-68). Mahwah, NL: LawrenceErlbaum.

Calabrese Barton, A. (2001). Capitalism, critical pedagogy, and urban science education: An interview with Peter McLaren. Journal of Research in Science Teaching, 38(8), 847-859. 
Carter, L. (2005). Globalisation and science education: Rethinking science education reforms. Journal of Research in Science Teaching, 42(5), 561-580.

Carter, L. (2008). Globalisation and science education: The implications for science in the new economy. Journal of Research in Science Teaching, 45(5), 617-633.

Carter, L. (2010). Globalisation and learner-centred pedagogies: Some thoughts. Canadian Journal of Science, Mathematics and Technology Education, 10(4), 223-231.

Castano, C. (2008). Socio-scientific discussions as a way to improve the comprehension of science and the understanding of the interrelation between species and the environment. Research in Science Education, 38(5), 565-587.

Charmaz, K. (2006). Constructing grounded theory: A practical guide through qualitative analysis. New York: Sage.

Chinn, P.W.U. (2007). Decolonizing methodologies and indigenous knowledge: The role of culture, place and personal experience in professional development. Journal of Research in Science Teaching, 44(9), 1247-1268.

Crawford, B.A. (2007). Learning to teach science as inquiry in the rough and tumble of practice. Journal of Research in Science Teaching, 44(4), 613-642.

De Boer, G. (2000). Scientific literacy: Another look at its historical and contemporary meanings and its relationship to science education reform. Journal of Research in Science Teaching, 37(6), 582-601.

Department for Education and Skills [DfES] (2004). The National Curriculum for England: Science, Key Stages 1-4. London: Qualifications and Curriculum Authority.

Eiglad, E., \& Bookchin, M. (2007). Social ecology and communalism. Oakland, CA: AK Press. Epstein, S. (1996). Impure science: AIDS, activism, and the politics of knowledge. Berkeley: University of California Press.

Foucault, M. (1991). Governmentality. In G. Burchell, C. Gordon, \& P. Miller (Eds.), The Foucault effect: Studies in governmentality (pp. 87-104). Hemel Hempstead, UK: Harvester Wheatsheaf.

Fuller, S. (2002). Social epistemology ( $2^{\text {nd }}$ ed.). Bloomington, IN: Indiana University Press.

Furberg, A., \& Ludvigsen, S. (2008). Students' meaning-making of socioscientific issues in computer mediated settings: Exploring learning through interaction trajectories. International Journal of Science Education, 30(13), 1775-1799.

Furman, M., \& Calabrese Barton, A. (2006). Capturing urban student voices in the creation of a science mini-documentary. Journal of Research in Science Teaching, 43(7), 667-694.

Gabbard, D.A. (editor) (2000). Knowledge and power in the global economy: Politics and the rhetoric of school reform. Mahwah, NL: Lawrence-Erlbaum.

Giroux, H.A., \& Giroux, S.S. (2006). Challenging neoliberalism's new world order: The promise of critical pedagogy. Cultural Studies $\leftrightarrow$ Critical Methodologies, 6(1), 21-32.

Gough, N. (1998). 'If this were played upon a stage': School laboratory work as a theatre of representation. In J. Wellington (Ed.), Practical work in school science: Which way now? (pp. 69-89). London: Routledge.

Gruenewald, D., \& Smith, G. (2008). Place-based education in the Global Age. New York: Lawrence Erlbaum Associates.

Harvey, D. (2010). The enigma of capital, and the crises of capitalism. London: Oxford University Press.

Hodson, D. (2003). Time for action: Science education for an alternative future. International Journal of Science Education, 25(6), 645-670. 
Hodson, D. (2008). Towards scientific literacy: A teachers' guide to the history, philosophy and sociology of science. Rotterdam: Sense.

Jenkins, E. (2000). 'Science for all': Time for a paradigm shift? In R. Millar, J. Leach \& J. Osborne (Eds.), Improving science education: the contribution of research (pp. 207-226). Buckingham, UK: Open University Press.

Kahn, R. (2010). Producing crisis: Green consumerism as an ecopedagogical issue. In J.A. Sandlin \& P. McLaren (Eds.), Critical pedagogies of consumption: Living and learning in the shadow of the "shopocalypse" (pp. 47-57). New York: Routledge.

Khishfe, R., \& Lederman, N.G. (2006). Teaching nature of science within a controversial topic: Integrated versus nonintegrated. Journal of Research in Science Teaching, 43(4), 395-418.

Kolst $\varnothing$, S (2001). Scientific literacy for citizenship: Tools for dealing with the science dimension of controversial socioscientific issues. Science Education, 85(3), 291-310.

Krimsky, S. (2003). Science in the private interest: Has the lure of profits corrupted biomedical research? Lanham, MD: Rowman \& Littlefield.

Lankshear, C. (2000). Literacy. In D.A. Gabbard (Ed.), Knowledge and power in the global economy: Politics and the rhetoric of school reform (pp. 87-94). Mahwah, NL: LawrenceErlbaum.

Latour, B. (2005). Reassembling the social: An introduction to actor-network-theory. Oxford: Oxford University Press.

Lawson, A.E. (2005). What is the role of induction and deduction in reasoning and scientific inquiry? Journal of Research in Science Teaching, 42(6), 716-740.

Lemke, J.L. (2001). Articulating communities: Sociocultural perspectives on science education. Journal of Research in Science Teaching, 38(3), 296-316.

Loving, C.C. (1991). The Scientific Theory Profile: A philosophy of science model for science teachers. Journal of Research in Science Teaching, 28(9), 823-38.

Lynas, M. (2008). Six degrees: Our future on a hotter planet (updated edition). London: Harper Perennial.

McLaren, P. (2000). Che Guevara, Paulo Freire, and the pedagogy of the revolution. Lanham, MD: Rowman \& Littlefield.

McMurtry, J. (1999). The cancer stage of capitalism. London: Pluto.

McQuaig, L., \& Brooks, N. (2010). The trouble with billionaires. Toronto: Viking.

Mignolo, W. (2007). Delinking: The Rhetoric of modernity, the logic of coloniality and the grammar of de-coloniality. Cultural Studies, 21(2), 449-514.

National Research Council [NRC] (1996). National science education standards. Washington: National Academy Press.

Pan, S.-Y. (2010). Exploring how globalization shapes education: Methodology and theoretical framework. Cultural Studies of Science Education, 5(2), 315-324.

Pedretti, E., \& Nazir, J. (in press). Currents in STSE education: Mapping a complex field, 40 years on. Science Education.

Putnam, R. (2000). Bowling alone: The collapse and revival of American community. New York: Simon \& Schuster.

Reich, R.B. (2007). Supercapitalism: The transformation of business, democracy, and everyday life. New York: Knopf.

Roth, W.-M. (2001). Learning science through technological design. Journal of Research in Science Teaching, 38(7), 768-790.

Roth, W.-M., \& Barton, A. (2004). Rethinking scientific literacy. London: RoutledgeFalmer 
Roth, W.-M., \& Désautels, J. (Eds.) (2002). Science education as/for sociopolitical action. New York: Peter Lang.

Roth, W.-M. (2009). Activism or science/technology education as byproduct of capacity building. Journal for Activism in Science \& Technology Education, 1(1), 16-31 (Available online at: http://www.wepaste.org/jaste1.1.html).

Sadler, T., \& Zeidler, D. (2004). The morality of socioscientific issues: Construal and resolution of genetic engineering dilemmas. Science Education, 88(1), 4-27.

Santos, W.L.P. dos (2009). Scientific literacy: A Freirean perspective as a radical view of humanistic science education. Science Education, 93(2), 361-382.

Schlosser, E. (2001). Fast food nation: The dark side of the All-American Meal. Boston: Houghton Mifflin.

Shapiro, H.S. (2000). Empowerment. In D.A. Gabbard (Ed.), Knowledge and power in the global economy: Politics and the rhetoric of school reform (pp. 103-110). Mahwah, NL: LawrenceErlbaum.

Sovacool, B.K. (2010). Erasing knowledge: The discursive structure of globalization. Social Epistemology, 24(1), 15-28.

Sperling, E., \& Bencze, J.L. (2010). 'More than particle theory': Citizenship through school science. Canadian Journal of Science, Mathematics and Technology Education, 10(3), 255266.

Stiglitz, J.E. (2003). Globalization and its discontents. New York: Norton.

Swartz, E. (2009). Diversity: Gatekeeping knowledge and maintaining inequalities. Review of Educational Research, 79(2), 1044-1083.

Usher, R. (2010). Consuming learning. In J.A. Sandlin \& P. McLaren (Eds.), Critical pedagogies of consumption: Living and learning in the shadow of the "shopocalypse" (pp. 36-46). New York: Routledge.

Weinstein, W.A. (2000). Ideology. In D.A. Gabbard (Ed.), Knowledge and power in the global economy: Politics and the rhetoric of school reform (pp. 95-101). Mahwah, NL: LawrenceErlbaum.

Wellington, J. (1998). Practical work in science: Time for a re-appraisal. In J. Wellington (Ed.), Practical work in school science: Which way now? (pp. 3-15). New York: Routledge.

Wenger, E. (1998). Communities of practice: Learning, meaning, and identity. New York: Cambridge University Press.

Wood, G.H. (1998). Democracy and the curriculum. In L.E. Beyer \& M.W. Apple (Eds.), The curriculum: Problems, politics and possibilities (pp. 177-198). Albany: SUNY Press.

Zeidler, D.L., Sadler, T.D., Simmons, M., \& Howe, E. (2005). Beyond STS: A research-based framework for socioscientific issues education. Science Education, 89(3), 357-377.

Ziman, J. (2000). Real science: What it is, and what it means. Cambridge: Cambridge University Press.

\section{ACKNOWLEDGEMENTS}

This paper would not have been possible without involvement of at least 50 teachers and at least 150 studentteachers who have been involved in STEPWISE development, implementation and evaluations. With regards to this report, contributions of the two teachers' whose work was briefly highlighted are particularly acknowledged and appreciated. Associated with this work with educators have been at least 10 graduate research assistants. Erin Sperling, a current doctoral student, has been particularly helpful in this work and her contributions are greatly appreciated. As well, generous and astute feedback on aspects of this paper from Dr. Steve Alsop, York University, Toronto, is gratefully acknowledged. Finally, this work has been funded through two generous grants from the Social Sciences and Humanities Research Council of Canada. 
Globalizing Students Acting for the Common Good, a manuscript for the special issue of JRST on

Globalization. ................ 22 of 22

\section{CONTACT INFORMATION}

\author{
John Lawrence Bencze \\ Associate Professor \\ Department of Curriculum, Teaching, and Learning \\ OISE, University of Toronto \\ 252 Bloor Street West \\ TORONTO, ON M5S 1V6 CANADA
}

Phone: 4169780079

Fax: 4169264744

E-mail: larry.bencze@utoronto.ca

Web Site: http://www.lbencze.ca

STEPWISE: http://www.stepwiser.ca 